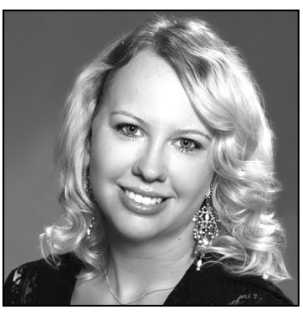

Egle Kalev

Doctoral Student

University of Tartu

\title{
The Possibility of Compensation for Health Damage in Cases of Uncertain Causes within the Victim's Sphere
}

\section{Introduction}

In numerous cases of harm to health, the inability to establish factual causation may be a serious obstacle to the plaintiff's success, because of causal uncertainty. ${ }^{{ }^{*}}$ In most tort cases, the victim must prove by a preponderance of the evidence that the tortfeasor's behaviour or act was a factual cause of the harm to the plaintiff. ${ }^{{ }_{2}}$ Yet, in certain kinds of situations, it is difficult or even impossible to prove the aforesaid. ${ }^{{ }^{3}}$ In cases of uncertain causation ${ }^{*} 4$, the standard rules of causation are often evaded ${ }^{*} 5$ and the plaintiff can only resort to the probability of the defendant having caused the damage. The defendant's liability to pay damages for the plaintiff's illness that was probably caused by the defendant's breach of duty, as in the infringement of compulsory regulations on occupational safety, is quite a confusing issue, especially when uncertain causes appear within the victim's sphere. An example of the latter is the scenario wherein the plaintiff's health had already been weak prior to the defendant's infringement of regulations. The main aim of this paper is to identify victims' chances to receive compensation for health damage in cases of uncertain causation pursuant to Estonian law and the case law of the Supreme Court of Estonia. In other words, the question is what the optimal solution should be in the case wherein the victim is only able to establish that the damage was probably caused by the defendant's unlawful act. To this end, I pose two main questions. Firstly, what are the uncertain causes in the victim's sphere, and how do the various causes affect

A. Fenyves et al. Tort law in the jurisprudence of the European Court of Human Rights. - Tort and Insurance Law, Vol. 30. Berlin 2011, p. 72 - DOI: http://dx.doi.org/10.1515/9783110260007; M.A. Berger. Eliminating general causation: Notes towards a new theory of justice and toxic torts. - Columbia Law Review 97 (1997)/VII, p. 2117.

2 S. Deakin et al. Markesinis and Deakin's Tort Law, 6th ed. Oxford: Clarendon Press 2008, p. 323; L. Wahlberg. Legal Questions and Scientific Answers: Ontological Differences and Epistemic Gaps in the Assessment of Causal Relations. PhD thesis, Lund 2010, p. 17.

3 S.M. Samii, A. Keirse. Taxonomy of asbestos litigation in the Netherlands: Duelling with causal uncertainty. - European Review of Private Law 2013/1, pp. 354-355.

4 Uncertain causality cases include, for example, those involving medical malpractice, competition, asbestos-related matters, lost or stolen lottery tickets, and lawyers' professional liability cases. See T.K. Graziano. All or nothing or partial liability in cases of uncertain causation. - European Private Law 2008/6, pp. 1013-1016.

5 J. Stapleton. Occam's razor reveals an orthodox basis for Chester v. Ashfar. - Law Quarterly Review 122 (2006), p. 427, as cited in S. Deakin et al. (see Note 2), pp. 261, 265. 
the plaintiff's chances of obtaining compensation? Secondly, how does the use of different approaches to paying damages, such as the all-or-nothing theory versus partial liability, affect the plaintiff's prospect of getting compensation from the defendant? I have chosen to focus predominantly on analysing the practice in the common-law countries and the most influential opinions of legal scholars to identify whether there are solutions for the issues dealt with in the article that are worth applying in the Estonian legal system and in the countries in continental Europe generally. In common law, many similar cases have been adjudicated $^{*} 6$; therefore, it is reasonable to start with this system and analyse UK court practice. So as not to overlook countries outside the common-law tradition, we examine some European private-law acts also, to create some moments of comparison. The Principles of European Tort Law ${ }^{*} 7$ (hereinafter 'the PETL') and the Draft Common Frame of Reference ${ }^{* 8}$, or DCFR, deal with the general issue. In addition, the Estonian courts have formed an opinion in cases of uncertain causation.

\section{Uncertain causes within the victim's sphere}

\subsection{The impossibility of applying the CSQN test in the case of multiple sources of damage}

According to Article 3:101 of the PETL, an activity or conduct is a cause of the victim's damage if, in the absence of that activity or conduct, the damage would not have occurred. Subsection 127 (4) of the Estonian Law of Obligations Act ${ }^{*}$ (hereinafter ' $\mathrm{LOA}^{\prime}$ ) stipulates that a person shall compensate for damage only if the circumstances on which that person's liability is based and the damage caused are related in such a manner that the damage is a consequence of the circumstances. In most cases of uncertain causality, the conditio sine qua non (hereinafter 'CSQN') test is not applicable, because there are multiple sources of damage or because the plaintiff was in poor health ${ }^{* 10}$ prior to the defendant's infringement of regulations. ${ }^{* 11}$ Therefore, absence of the wrongdoer's act could not usually eliminate the outcome, or at least we cannot know for a fact what the situation would be like if we were able to remove the wrongdoer's behaviour retroactively. In such cases, one cannot be certain whether the damage is caused by a pre-existing health condition of the plaintiff, the victim's noxious habit, predisposition to the disease, or the tortfeasor's unlawful act. Furthermore, in many cases of uncertain causation, it cannot be established with certainty whether the disease was caused by, say, a nearby factory (the 'excess risk') or other causes (the 'background risk'). ${ }^{*}$ The risk factors may involve personal lifestyle choices or, as in the case of genetic factors, circumstances outside the exposed person's control. ${ }^{*} 13$ Therefore, uncertainty surrounding the cause of damage may exist even if there are no other persons who could have caused the damage and could be named as defendants.

6 For example, with regard to employees in Germany, there are workers' compensation carriers who take care of, for instance, victims of toxic substances, and the German Supreme Court has not adjudicated on any cases of this kind. In Germany, there is a partial-liability theory in use in other cases of uncertain causation, according to which each defendant should be held liable for a fraction of the harm. See G. Wagner. Asbestos-related diseases in German law. - European Review of Private Law 2013/1, p. 328.

7 Principles of European Tort Law (PETL). Available via http://www.egtl.org/ (most recently accessed on 3.1.2014).

8 Draft Common Frame of Reference (DCFR). Book VI. Available at http://ec.europa.eu/justice/contract/files/europeanprivate-law_en.pdf (most recently accessed on 3.1.2014).

9 Estonian Law of Obligations Act. Available at http://www.legaltext.ee/et/andmebaas/tekst.asp?loc=text\&dok=X30085K7 \&keel=en\&pg=1\&ptyyp=RT\&tyyp=X\&query=v\%F5la\%F5igusseadus (most recently accessed on 20.1.2014).

10 The factors within the victim's own sphere mentioned in Article 3:106 of the PETL that might have an impact on the risk, apart from the general health of the victim, are ageing, gender, genetic predisposition, noxious eating or drinking habits, living environment, previous and current occupational conditions, and others. See M.-M. Casals. Causation conundrums: Introduction to the annotations to Sienkiewicz v. Greif (UK) Ltd. - European Review of Private Law 2013/I, p. 307.

11 The CSQN test is not applicable in cases wherein elimination of the defendant's act or substitution for the inactivity cannot show the exact cause of the damage to health or if there are many possible causes of damage. See B. Winiger (ed.). Digest of European Tort Law, Volume 1: Essential Cases on Natural Causation. Vienna: Springer-Verlag 2007, p. 47.

12 R. Young et al. Causality and causation in tort law. - International Review of Law and Economics 2004/24, p. 508. - DOI: http://dx.doi.org/10.1016/j.irle.2005.01.007.

13 J.B. Cologne et al. Uncertainty in estimating probability of causation in a cross-sectional study: Joint effects of radiation and hepatitis-C virus on chronic liver disease. - Journal of Radiological Protection 2004/24, p. 142. 


\subsection{Noxious habits and living environment as causes within the victim's sphere}

The plaintiff's noxious habits and living environment are factors that render it more complicated to determine whether the disease is a result of the defendant's breach of duty. Instead, the cause might be the plaintiff's noxious habits or polluted living environment. ${ }^{* 14}$ It is questionable whether noxious habits and living in a polluted environment could be treated as intentional behaviour by the victim or contributory negligence causing harm to his or her health that may serve as a basis for reduction in damages.

A typical example of a risk in the victim's sphere is a situation wherein the plaintiff has smoked for years and at the same time has been exposed to asbestos dust for a prolonged time at work. ${ }^{*} 15$ Legal scholars S.M. Samii and A. Keirse have pointed out that even when a disease can be attributed to a single possible cause, as in the case of mesothelioma, ${ }^{* 16}$ it cannot be disregarded that there may be multiple sources of exposure. ${ }^{*} 17$ For instance, smoking tobacco and being exposed to asbestos dust could both cause lung cancer. There are two questions: to what extent the employer should be held liable for the employee's lung cancer and whether tobacco-smoking constitutes contributory negligence. In this case, the aetiology of the disease plays a role (see Subsections 3.1 and 3.2, below). ${ }^{* 18}$ Accordingly, in spite of the fact that both smoking of tobacco and inhalation of asbestos dust may cause cancer, we know from the statistical data that, for example, mesothelioma is caused by asbestos exposure, not by smoking: at least $90 \%{ }^{* 19}$ of the cases of mesothelioma seen result from exposure to asbestos. Therefore, in my opinion, in the case of mesothelioma it is possible not to take into account the smoking history of the plaintiff and not to reduce the damages accordingly.

On the other hand, asbestosis is regarded as a cumulative or 'divisible' disease. In the case of asbestosis, unlike mesothelioma, the plaintiff should demonstrate that the concentration of inhaled asbestos dust from the air was substantial, and in this case it is possible for tobacco-smoking to constitute contributory negligence. ${ }^{* 20}$ I agree with the conclusion of the Supreme Court of Estonia that use of tobacco cannot be regarded as the plaintiff's intentional act to cause the cancer or as an ordinary risk of life for the victim; rather, it should be treated as the plaintiff's contribution to the cause of damage or increase in damage. ${ }^{{ }_{21}}$ Under $\$ 139$ (3) of the LOA, in cases of health damage, the compensation for damage may be reduced only if the plaintiff showed gross negligence ${ }^{{ }^{2} 2}$ or intent to cause damage. ${ }^{* 3}$

14 In her PhD thesis, Swedish legal scientist Lena Wahlberg gave a good example highlighting the complexity of the background risks by describing the kinds of factors that should be taken into account in solving of cases that involve uncertain causality. In the example, a 6o-year-old man who has been exposed to the defendant and subsequently developed lung cancer may be known to have spent several years cooking food in a badly ventilated kitchen in Taiwan, climbed Mount Everest twice, and lived in a house with a radon issue in which he had a diet rich in vegetables. Some of these factors may be known or believed to be associated with lung cancer even if details about their interaction with the defendant's exposure are largely unknown. See L. Wahlberg (Note 2), p. 143.

15 In the UK case Badger $v$. Ministry of Defence, Mr Badger had been smoking for 45 years and had for 33 years been exposed to asbestos at work, through employer negligence. Asbestos exposure or heavy smoking is only one example of risk within the plaintiffs sphere. EWHC 2941 (QB), 16.12.2005, Badger v. Ministry of Defence. Available at http://lexisweb.co.uk/cases/2005/ december/badger-v-ministry-of-defence (most recently accessed on 1.2.2014).

16 Cases of mesothelioma have been reported after household exposure of family members of asbestos workers and in individuals without occupational exposure who live close to asbestos mines, for example. Details are available at http://www.atsdr. cdc.gov/asbestos/asbestos/health_effects/index.html (most recently accessed on 12.1.2014).

17 S.M. Samii, A. Keirse (see Note 3), p. 348.

18 J. Stapleton (see Note 2), p. 1013.

19 Fairchild v. Glenhaven Funeral Services Ltd, 2002 UKHL 22; 2003, paragraph 22.

$20 \quad$ S.M. Samii, A. Keirse (see Note 3), p. 358.

21 The Supreme Court of Estonia has said that the plaintiff's intention to cause damage as specified in \$139 (3) of the LOA refers to the victim's intention to harm himself, not intentional acts by the plaintiff that are regarded only as an additional cause of the damage. See CCSCd, 22.10.2008, 3-2-1-85-08, K.P. v. K.L. and R.L., paragraph 14 (in Estonian).

22 According to the DCFR, there is negligence by the defendant if a person does not meet the standard of care that could reasonably be expected in the circumstances. See C. Von Bar, E. Clive (eds). Principles, Definitions and Model Rules of European Private Law: Draft Common Frame of Reference (DCFR), Vol. 4. European Law Publishers 2009, p. 338.

23 In the case of an insubstantial possibility that the victim him- or herself too may have caused the damage, the defendant has to pay all damages under the all-or-nothing approach, in favour of the victim. The liability of the defendant is excluded if the plaintiff caused his or her health damage intentionally. CCSCd, 21.3.2007, 3-2-1-2-07, K.V.v. V., paragraph 14 (in Estonian); CCSCd, 31.5.2007, 3-2-1-54-07, I.A. v. AS V., paragraphs 12, 14 (in Estonian). 
In his article on uncertain causality, T.K. Graziano asks whether it is not an ordinary risk of the victim's life that in some situations a plaintiff cannot prove a causal link with the degree of probability required by law. ${ }^{* 24}$ In the joined cases before the UK Supreme Court Sienkiewicz v. Greif (UK) Ltd and Knowsley Metropolitan Borough Council v. Willmore ${ }^{*} 25$ (hereinafter 'Sienkiewicz'), the victim's disease was either caused by exposure to asbestos fibres at work or caused by the background risk posed by the non-tortious low-level atmospheric asbestos dust. This means that the disease was caused either by wrongful behaviour of the defendant or by an 'innocent' cause or natural factor. ${ }^{* 26}$ In this case, the court settlement was in accordance with Article 3:106 of the PETL, according to which the victim has to bear his or her loss to the extent corresponding to the likelihood that it may have been caused by an activity, occurrence, or other circumstance within his or her own sphere. Therefore, according to the PETL, a person in poor health has to bear the normal risk of living. Although the Estonian courts have said that issues with the plaintiff's state of health do not exclude the defendant's liability, ${ }^{*} 2$ the Supreme Court of Estonia has applied a principle similar to those set forth in the PETL according to which the defendant is not liable for the time during which the plaintiff's health was harmed by another source of exposure or by the defendant's lawful behaviour. ${ }^{* 28}$

The defendant should probably not be held liable for the damage to the extent that it has been caused by the victim's noxious habits. The extent of the plaintiff's liability may be assessed on the bases of the duration and intensity of wrongdoing. Estonian law is in accordance with Article 5:102 (2) of Book VI of the DCFR ${ }^{* 29}$, stipulating that if the fault of the plaintiff is insubstantial, reparation is not to be reduced. The scholars of common law have also said that if the activity exceeds the limits set for pollution, the 'substantial factor' principle is applied in cases wherein the defendant's act is sufficient for causing the damage and at the same time there is doubt of the damage having been caused by some other factor (the act of a third party or the realisation of some other risk). ${ }^{*} 30$ The fault may be insubstantial-for instance, in the case of living in an area with low-level air pollution. It is my opinion, on the one hand, that it is not acceptable to say that living in a city environment constitutes contributory negligence or the plaintiff's intention to cause damage. This is part of the victim's normal risk of living, comparable to working in conditions wherein the employer's activities are in accordance with the law. ${ }^{*}{ }^{1}$ On the other hand, one could ask whether the outcome might be different when the person begins to live or work in a heavily and unlawfully polluted area. In theory, such behaviour by the plaintiff may be treated as contributory negligence and the compensation for the damage suffered may be reduced under Subsection 139 (3) of the LOA. The amount of reduction may depend on how long the person remained in the polluted environment.

\subsection{Pre-existing health conditions as a cause within the victim's sphere}

The second type of case is that in which it is not possible to determine whether the disease is a result of the defendant's breach of duty, the plaintiff's pre-existing health condition (such as a chronic disease), or the plaintiff's predisposition to the illness (for example, genetic susceptibility). Estonian legal scholar

24 T.K. Graziano (see Note 4), p. 1030. I would add that smoking in itself is not an ordinary risk of life but is a risk that the plaintiff bears. An example of a natural risk of life might be a case wherein there is some pollution near the victim's home but that pollution does not exceed the established limits.

25 UKSC 10, 9.3.2011, Sienkiewicz v. Greif (UK) Ltd and Knowsley Metropolitan Borough Council v. Willmore, paragraph 27. Available at http://www.theguardian.com/law/interactive/2011/mar/10/mesothelioma-school-asbestos-supremecourt (most recently accessed on 20.3.2014).

26 Ibid., paragraphs 61-111 (if the defendant's behaviour materially increases the risk of contracting the disease, the tortfeasor bears the responsibility); G. Wagner (see Note 6), p. 320.

27 CCSCd, 10.4.2013, 3-2-1-21-13, D. Chechulina v. Eesti Energia Kaevandused AS, paragraph 14 (in Estonian); CCSCd, 21.3.2007, 3-2-1-2-07, K.V.v. V., paragraph 14 (in Estonian); CCSCd, 31.5.2007, 3-2-1-54-07, I.A. v. AS V., paragraphs 12, 14 (in Estonian).

28 CCSCd, 13.1.2010, 3-2-1-145-09, R.H. v. AS A., paragraph 15 (in Estonian); CCSCd, 15.10.2003, 3-2-1-89-03, E. Kotkas v. ETK Majad, paragraph 25 (in Estonian); CCSCd, 12.1.2000, 3-2-1-2-oo, N. Prueli v. The Republic of Estonia (in Estonian); T. Tampuu. Lepinguväliste võlasuhete õigus ['Tort Law']. Juura 2007, p. 170 (in Estonian).

29 Draft Common Frame of Reference (see Note 8).

30 S.M. Samii, A. Keirse (see Note 3), p. 348.

31 CCSCd, 28.4.1999, 3-2-1-45-99, A. Kägu v. AS Tartu Auto and AS Tartu Autoveod (in Estonian); CCSCd, 22.12.2000, 3-2-1-139-oo, R. Hallikv. AS Tartu Autoremonditehas (in Estonian). See also Note 24. 
T. Tampuu has discussed the question of whether the plaintiff's unusual sensitivity to or receptiveness of the tortfeasor's unlawful act excludes causality. ${ }^{*}{ }^{3}$

Legal scholar D. Robertson has said: 'We will take into account only those threats that are so far advanced and so nearly certain at the time of the accident that any attempt to ignore their functional identity with preexisting conditions would seem dishonest." ${ }^{*} 33$ Another legal scholar, B. Markesinis, has pointed out that in England $^{*} 34$ and the United States the tortfeasor should not be held liable for the effects of a pre-existing condition of the plaintiff. This conclusion is reasonable because if the plaintiff had a poor condition of health before the tortfeasor's unlawful act, there is no causal link between the act and the illness. However, in my opinion, whether or not the defendant's infringement of regulations worsens the plaintiff's state of health is important. T. Tampuu has argued that if the tortfeasor's act even slightly worsens the plaintiff's illness, the courts may decide that the defendant must pay some compensation. ${ }^{*} 35$ According to the practice of the Estonian courts, ${ }^{*}{ }^{36}$ the defendant's liability is not excluded even if the plaintiff's health was already harmed before the defendant's behaviour. ${ }^{*} 37$ This position is in accordance with Article 4:101 (2) of Book VI of the DCFR, which stipulates that in cases of personal injury or death, the injured or dead person's predisposition with respect to the type or extent of the injury sustained is to be disregarded. ${ }^{*}{ }^{8} \mathrm{I}$ believe that, according to the DCFR, the liability of the defendant cannot be excluded for such reasons as the plaintiff's health having been weak or the victim being old and likely to have caught the illness from another source and died in the near future anyway. In common-law cases wherein the victim had been ill before the defendant's infringement of regulations, the 'eggshell skull' rule is employed. According to this rule, 'any person who injures another should not be exonerated because the victim's health was previously unsound or because the victim suffered from a physical or mental affliction [...]. A person who injures a victim in weak health cannot demand to be put in the position which would have existed if the victim had been healthy; also, in cases of psychological injury, the injury is in principle attributable to the person who inflicted the injured person's particular vulnerability'. ${ }^{*} 9$ When the eggshell skull rule is applied, the defendant has to accept the plaintiff as he or she is, taking into account his or her weak health condition. ${ }^{*} 40$ Moreover, in common law a wrongdoer must 'take his victim as he finds him'. ${ }^{* 1}$ However, the special susceptibility of the victim may be a circumstance that reduces the damages. ${ }^{*}{ }^{42}$ The Supreme Court of Estonia has expressed its opinion that

\footnotetext{
T. Tampuu (see Note 28), p. 172 (in Estonian).
}

33 D. Robertson. The common sense of cause in fact. - Texas Law Review 75 (1997), pp. 1765, 1798, as cited in S. Deakin et al. (see Note 2), p. 333.

34 In the UK, the House of Lords has said that pre-existing conditions have to be taken into account for avoidance of offending the principle that a tortfeasor should not be made to pay for something that we know he had nothing to do with. See the 1982 review of Jobling $v$. Associated Dairies available at http://www.e-lawresources.co.uk/Jobling-v-Associated-Dairies. php (most recently accessed on 10.12.2013).

35 T. Tampuu (see Note 28), p. 173 (in Estonian); see Subsection 127(6) of the LOA.

36 CCSCd, 16.6.2010, 3-2-1-55-10, R.D. v. The Republic of Estonia, paragraph 30 (in Estonian).

37 CCSCd, 22.5.2003, 3-2-1-50-03, L. Madisson v. AS Estonian Match, AS Paide KEK and the Republic of Estonia, paragraph 31 (in Estonian). In my considered opinion, the above-mentioned court position may be correct under some circumstances, but the opinion on the referred case 3-2-1-50-03 (para. 31) does not say that the employer's liability is not excluded if the employee had been ill before the hiring. However, it does state that the fact that the plaintiff was in poor health before the plaintiff started the work does not exclude the employer's unlawful behaviour. It says nothing about excluding liability and causality. Therefore, courts have to assess whether the employer's unlawful behaviour can worsen the plaintiff's health or not. If the plaintiff's health worsens during work at the employer's work location, a causal link exists between the infringement of regulations by the employer and the deterioration in the employee's health.

38 DCFR. Available at http://translex.uni-koeln.de/output.php?docid=400270 (most recently accessed on 5.11.2013).

39 DCFR (see Note 8), pp. 3573-3574.

40 T. Tampuu (see Note 28), pp. 172-173 (in Estonian).

$41 \quad$ DCFR (see Note 8), p. 3592.

42 The fact that the plaintiff's health was damaged before he started to work at AS Eftico does not exclude the defendant's unlawful behaviour. If the plaintiff's own gross negligence created predisposition to the increase in damage, the court may reduce the compensation for damage or refuse to award compensation, with the exact outcome depending on the level of the plaintiff's guilt. See CCSCd, 22.5.2003, 3-2-1-50-03, L. Madisson v. AS Estonian Match, AS Paide KEK and the Republic of Estonia, paragraph 31 (in Estonian). The plaintiff's prior health condition is under question in the case of assessment of the extent of paying damages. What to do is debatable in a situation wherein the victim's health was damaged before the defendant's act when the additional damage is not reparable without payment of full compensation. According to the Supreme Court of Estonia, it is not possible to reduce the excess in the compensation under Subsection 127(5) of the LOA - the Supreme Court of Estonia has found that a situation wherein it is not possible to remove the consequences of the plaintiff's health damage without improving the previous health condition of the plaintiff should be treated as forced enrichment. See CCSCd, 25.3.2013, 3-1-1-31-13, D.V. v. Andrei Katsov, paragraph 12 (in Estonian). 
one of the circumstances within the victim's sphere that exclude or reduce the defendant's obligation to pay compensation for harm to health is the plaintiff's age. ${ }^{*} 43$ If the plaintiff would have lost his or her income on account of his or her advanced age irrespective of the infringement of regulations by the defendant, then it may be unfair to claim damages (for loss of income) from the employer. In that case, the plaintiff has no obligation to prove that his or her age (or previous health condition) was not the cause of the damage. ${ }^{* 44}$ In cases of uncertain causation, the plaintiff's burden of proof is not usually as strict as in other tort cases. Therefore, easing the plaintiff's onus of proof by reversing the burden of proof 45 is one possibility for enabling the victim to get compensated where there is uncertain causation within the victim's sphere. Subsection 139 (1) of the LOA stipulates that if damage is caused in part by circumstances dependent on the injured party or due to a risk borne by the injured party, the amount of compensation for the damage shall be reduced to the extent that said circumstances or risk contributed to the damage. The outcome may be unclear if the defendant argues that the damage was caused by a circumstance lying within the victim's sphere. There is some question as to who has to prove the claim. If the defendant appeals to §139 (3) of the LOA, the defendant has to prove his or her arguments, ${ }^{*} 46$ although the victim is the one who possesses knowledge and documents pertaining to his or her state of health. My point of view is that the courts should consider the option of partially easing the defendant's burden of proof only in certain cases-for instance, if it is impossible or very complicated for the defendant to prove that his or her own behaviour was not the cause of the damage and that the reason for the harm was the other set of circumstances. Usually, the scope of the damage and the party causing it are not clear and, therefore, courts should estimate the degree of probability of potentially health-damaging combining circumstances or a risk in the victim's sphere causing the damage. ${ }^{*} 7$ In my opinion, it should be considered whether the Law of Obligations Act of Estonia should be supplemented with a provision that stipulates the following: in those cases wherein the plaintiff can verify only the probability that the defendant has caused the death or health damage suffered by the victim, the court should award compensation in accordance with the degree of probability of the defendant having caused the damage.

The defendant's obligation to pay damages and the amount of that compensation depend on the theories chosen for application-for example, whether the all-or-nothing or the proportional-liability approach is used.

\section{Theories of paying damages}

\subsection{Declining use of the all-or-nothing approach}

According to legal scholar K. Oliphant, most European countries and the United States have been using the all-or-nothing principle when awarding damages. ${ }^{*} 8$ However, as is shown below, this tendency is changing.

The established threshold for certainty varies with the country. Often, UK courts ${ }^{*} 49$ have discussed cases of uncertain causation. In the common-law literature, there are various standards of proof, among them 'the preponderance of the evidence" ${ }^{, *}$, also known as the balance of probabilities, and 'a reasonable

43 CCSCd, 14.10.2003, 3-2-1-92-03, V. Kivi v. AS ETK Leib (in Estonian).

44 M. Faure. Causal uncertainty, joint and several liability and insurance. - H. Koziol, J. Spier (eds). Tort and Insurance Law, Vol. 10. Springer 2003, p. 82. - DOI: http://dx.doi.org/10.1007/978-3-7091-6094-7_6. See also the following cases of the Supreme Court of Estonia: CCSCd, 6.10.2010, 3-2-1-68-10, V.U.v. The Republic of Estonia, paragraph 10; 7.11.2002, 3-2-1107-02, Stanislav Adamtsevits v. AS Dvigatel, paragraph 7; 14.10.2003, 3-2-1-92-03, Vilma Kiviv. AS ETK Leib, paragraphs 26, 27; 26.9.2006, 3-2-1-53-06, A.S. v. AS E., paragraph 11 (all in Estonian); CCSCd, 3.10.2006, 3-2-1-78-o6, H.M. v. AS V., paragraph 13 (in Estonian).

45 CCSCd, 7.12.2011, 3-2-1-68-11, V.G. v. The Republic of Estonia, paragraph 10 (in Estonian); CCSCd, 9.5.2012, 3-2-1-51-12, N. Grigorjev v. Narva Elektrijaamad $A S$, paragraph 11 (in Estonian).

46 See also P. Varul et al. Law of Obligations Act I. Tallinn 2006, Section 139, Comment 4.6 (in Estonian).

47 Ibid.

48 K. Oliphant. Uncertain factual causation in the third restatement: Some comparative notes. - William Mitchell Law Review $37(2011) / 3$, p. 1624 .

49 For example, the standard of proof in German law is 'beyond reasonable doubt' (50 or 51 per cent is not set as a threshold). See G. Wagner (Note 6), p. 319.

50 B. Black, D.E. Lilienfeld. Epidemiologic proof in toxic tort litigation - Fordham Law Review 52 (1983-1984), p. 735. 
degree of certainty'. ${ }^{31}$ Formerly, the plaintiff, who bore the burden of proof, had to make his or her case to the 'more probable than not' or 'more likely than not' standard; the plaintiff had to demonstrate that his or her case as put forth was probable ${ }^{*} 52$, not merely possible. ${ }^{*} 53$ The all-or-nothing approach does not take into consideration the calculated probability that the defendant caused the damage. ${ }^{*} 54$ Legal scholars S.M. Samii and A. Keirse have opined that the all-or-nothing approach will inevitably foster a tipping point between all and nothing. They find that this tipping point is then hard to find, asking: 'How likely must the probability be for the risk of the entire damage compensation to be placed with the tortfeasor, or how unlikely should this probability be for the compensation of the damages suffered by the victim to be dismissed altogether?"*55

In cases of uncertain causation, in addition to reallocating the burden of proof, courts should ease the CSQN test in plaintiffs' favour. ${ }^{*} 56$ According to the European Court of Human Rights (hereinafter 'the ECHR'), the causal link is qualified as 'clear', 'direct', or 'sufficient'; the link cannot be too remote. ${ }^{*}{ }^{57}$ In the English case Fairchild $v$. Glenhaven Funeral Services ${ }^{*} 58$ (hereinafter 'Fairchild'), the House of Lords relaxed the usual 'balance of probabilities' test and substituted the test of 'materially increasing risk of harm ${ }^{, * 59}$ of disease when establishing the causation requirement. This rule, referred to as the Fairchild exception $^{* 60}$, addresses the impossibility of proving causation. The case represents a new direction in solving cases of uncertain causality. The Fairchild exception also covers situations of uncertainty wherein the harm was caused by a single potential tortfeasor, the claimant himself, or a natural cause. ${ }^{* 61}$ The Supreme Court of Estonia has used the term 'may hold': causation is established if the defendant's behaviour is in such a connection with the plaintiff's damage that the damage may hold the consequence of the defendant's behaviour. ${ }^{*}{ }^{62}$ The term 'may hold' is similar in practice to 'is probable'.

Although the 'materially increase the risk' test itself enables easing of the causality requirement, there are various legal devices under the all-or-nothing approach in addition to material increase in the risk, among them shifting the burden of proof and the 'doubling the risk' test, that may lead to awarding compensation for all the harm suffered by the claimant even if there is no doubt that the tortfeasor may not have caused it in full or at all. ${ }^{*} 63$ A good example is Sienkiewicz ${ }^{*} 64$, in which a likelihood existed that the cause of the damage was within the victim's sphere, of such a nature as atmospheric exposure, but the defendant still was held liable for the entirety of the damage. Accordingly, the Fairchild exception is not applicable where one source of the risk of the injury, such as atmospheric exposure, is known to have been an innocent source unrelated to the defendant. ${ }^{*} 5$ As is established above, today's epidemiological data allow stating in

51 F. Sobczak. A comparison between Dutch and English laws with regard to the problem of multiple causation in asbestosrelated cases. - European Review of Private Law 2010/6, p. 1164.

$5^{2}$ M. Parascandola. Evidence and association: Epistemic confusion in toxic tort law. - Philosophy of Science 63 (1996), p. 169. DOI: http://dx.doi.org/10.1086/289949.

53 G. Wagner has provided the following good example with respect to the 'more probable than not' theory: 'If the background risk of contracting mesothelioma is 30 per million, and the exposure for which the tortfeasor is responsible increased it to 52 per million, then the likelihood of a given victim contracted to the disease from occupational exposure is 30 of 52 or 57.69 per cent and thus it is more likely than not that the exposure was the reason for the harm' (G. Wagner (see Note 6), p. 324).

54 L. Bieri, P. Marty. The discontinuous nature of the loss of chance system. - Journal of European Tort Law 2 (2011), p. 24. DOI: http://dx.doi.org/10.1515/jetl.2011.23.

55 S.M. Samii, A. Keirse (see Note 3), p. 370; F. Sobczak (see Note 51).

56 S. Deakin et al. (see Note 2), p. 324.

57 A. Fenyves et al. (see Note 1), p. 467.

$58 \quad$ Fairchild v. Glenhaven Funeral Services Ltd (see Note 19), AC 32.

59 "Materially increased the risk of the victim of suffering the harm" means that as long as it has not been de minimis then no matter how small this increase has been, the defendant can be held liable for the whole harm suffered by the claimant' according to M.-M. Casals (see Note 10), p. 309.

60 The Fairchild exception treats the risk of contracting mesothelioma as the damage, according to T. Weir. Making It More Likely Versus Making It Happen. The Cambridge Law Journal (2002), p. 519. Available at http://journals.cambridge.org/ action/displayAbstract?fromPage $=$ online\&aid $=138011 \&$ fileId $=$ Sooo8197302301703 (most recently accessed on 3.3.2014).

61 G. Wagner (see Note 6), p. 327.

62 CCSCd, 7.12.2011, 3-2-1-68-11, V.G. v. The Republic of Estonia, paragraph 12 (in Estonian); CCSCd, 6.10.2010, 3-2 1-68-10, V.U.v. The Republic of Estonia, paragraph 10 (in Estonian).

63 M.-M. Casals (see Note 10), p. 310.

64 UKSC 10, 9.3.2011, Sienkiewicz v. Greif (UK) Ltd and Knowsley Metropolitan Borough Council v. Willmore (see Note 25).

65 J. Stapleton. Loss of the chance of cure from cancer. - The Modern Law Review 2005, p. 1002. - DOI: http://dx.doi. org/10.1111/j.1468-2230.2005.570_1.x. 
the case of some specific diseases that, for instance, only one type of dust might cause the relevant disease. From my point of view, in the case of such diseases it may be suitable to apply the all-or-nothing principle. For example, the all-or-nothing principle may be applicable in the case of mesothelioma, because even one-off, low-level asbestos exposure can cause this form of lung cancer. ${ }^{* 66}$ On this basis, it can be said that, generally, in cases of indivisible injuries the defendant may be held liable for the whole of the damage.

The Supreme Court of Estonia has settled one case that is tied in with the all-or-nothing approach. The court found a doctor's findings on health damage and the defendant's activities exceeding pollution limits not to be substantial as proof establishing causation between the tortfeasor's behaviour and the damage. ${ }^{* 67}$ The doctor had concluded that the disease suffered was a result of the relevant supermarket's activities (noise, exhaust, and odours) ${ }^{*} 68$ that breached the required standards and exceeded permitted limits. The Supreme Court of Estonia found that the plaintiff had not proved his argument that the defendant's breach of duty caused the disease. In this case, the Fairchild exception could have been applied. It specifies that if the defendant's unlawful activity materially increases the risk of the plaintiff contracting the disease, causation is established. A case similar to the Estonian one is the UK's McGhee v. National Coal Board ${ }^{* 69}$ case, in which it could not be clearly established with medical evidence that the plaintiff would have suffered the health damage anyway. ${ }^{*} 70$ In this case, Lord Wilberforce said: 'Where a person has, by breach of duty of care, created a risk, and injury occurs within the area of that risk, the loss should be borne by the defendant unless he shows that it had some other cause.' It is thus that the decision in the above-mentioned case heard by the Supreme Court of Estonia does not take into account the fact that this is an uncertain causality case and the requirement that the plaintiff must establish causation should be eased. Therefore, the Supreme Court of Estonia resorted to the all-or-nothing approach. However, from my point of view, estimating the liability on the basis of probabilities might offer a better solution. The all-or-nothing rule may not be equitable for the plaintiff or the defendant in cases of uncertain causation. Application of that approach may lead to compensation for the harm that is not caused by the defendant, or, conversely, the plaintiff may not receive any compensation at all if unable to establish causality with the required level of certainty. All in all, if the all-or-nothing approach is used, the final decision is not going to be equitable for the parties.

\subsection{Liability based on probability}

\subsubsection{Use of the theory of probability to estimate causality}

One way of reducing the plaintiff's burden of proof of causation is to apply liability theories based on probabilities instead of awarding compensation for all of the damage. ${ }^{*} 71$ The Fairchild decision says that each defendant should be held liable only in proportion to his or her degree of fault, in accordance with the duration and intensity of the exposure for which he or she was responsible. ${ }^{*} 72$ For instance, experts might assess there to be, say, a 30\% probability that a certain activity may cause a specific health consequence for a particular individual. This probability is referred to in the literature as the 'probability of causation' and can be estimated by dividing the excess risk by the sum of the background risk and the excess risk. ${ }^{*} 73$ This probability can be used for determining whether victims shall receive compensation and how much. ${ }^{*} 74$ Payment of damages should, therefore, be divided between or among potential tortfeasors in proportion to the probability of each having caused the harmful event. ${ }^{*}{ }^{75}$ Nowadays, Estonian courts have been applying

66 Health Council of the Netherlands. Asbestos: Risks of Environmental and Occupational Exposure. The Hague, Publication 2010/10, pp. 19-20; S.M. Samii, A. Keirse (see Note 3), p. 345.

67 CCSCd, 28.5.2008, 3-2-1-43-08, Viktor Petkevitš v. Maxima Eesti Ö̈ (in Estonian).

68 Furthermore, the ECHR has found that the noise, odour, and fumes from a local municipality's waste-treatment plant deprived the applicant of the effective enjoyment of her right to respect for her home and her private and family life. See the case Lopez Ostra v. Spain, 9.121994, no. 16798/90, paragraph 65.

69 S. Deakin et al. (see Note 2), p. 250.

$70 \quad$ Ibid., p. 249.

$71 \quad$ T.K. Graziano (see Note 4), p. 1019.

$72 \quad$ S. Deakin et al. (see Note 2), p. 255

73 M.-M. Casals (see Note 10), p. 305.

74 R. Young et al. (see Note 12), p. 517.

75 S. Shavell. Uncertainty over causation and the determination of civil liability. - Journal of Law and Economics 1985, pp. 587-609 - DOI: http://dx.doi.org/10.1086/467102; R. Young (see Note 12), p. 508. 
proportional liability in cases of health damage. ${ }^{*} 6$ Even though most of these cases deal with two or more potential tortfeasors, the principles used in partial-liability theories should be suitable for application also in cases wherein the uncertain cause appears within the victim's sphere. The Supreme Court of Estonia has explained: 'In cases of unclear division of liability, courts should award compensation for damage in proportion to the probability that the person in question had probably caused the damage."*77 This decision is in accordance with Article 3:103 (1) of the PETL, which stipulates that, in cases of multiple activities that each alone would have been sufficient to cause the damage wherein uncertainty remains as to which one actually caused it, each activity is regarded as a cause to the extent corresponding to the likelihood that it may have caused the harm to the victim. It may be possible to use this approach by analogy in cases involving the victim's sphere, as the latter also involve multiple possible sources of damage. Whether the uncertain causes come from the victim's or a third party's sphere should not make any difference. ${ }^{*} 78$

However, there is a different view on 'probabilistic causation', taking a radical form in common law. That theory is explained thus: 'It would hold the defendant whose wrongful conduct is shown to have cost the victim an appreciable but lower than 50 per cent chance of avoiding the injury in question liable for full damages." ${ }^{*} 79$ As B. Markesinis has noticed, '[o]nly a small minority of analysts think this approach has much promise'. I agree with that perspective, because it is unfair to compensate for all of the damages in cases wherein there was a lower than $50 \%$ chance of avoidance of the injury.

As the all-or-nothing approach is applicable in the case of so-called indivisible injuries (usually in such cases as that of mesothelioma, caused by the living or work environment), the principles of liability based on probabilities are applicable in the case of divisible injuries such as asbestosis, with the tortfeasor being liable only for the proportion of the damage that would not have occurred without the defendant's breach of duty. ${ }^{*} 80$ Divisible injuries may be caused by the noxious habits of the plaintiff, the living or work environment, or predisposition of the plaintiff. In the case of asbestosis, unlike that of mesothelioma, it should be shown that the concentration of inhaled asbestos dust in the air was substantial; accordingly, the plaintiff's burden of proof is stricter than in the case of mesothelioma. ${ }^{*} 81$ In cases of divisible injuries, the LOA does not exclude application of partial liability based on probabilities. Therefore, it is my clear and considered opinion that Estonian courts should apply liability theories based on probabilities in most cases of uncertain causation. Indivisible diseases, however, should constitute an exception.

\subsubsection{Different versions of liability based on probabilities}

The Estonian courts also have abided by the principle that in the case of every single victim, the court has to estimate the probability that the defendant has caused the damage and require compensation for the damage in proportion to the probability of causation. ${ }^{*}{ }^{2}$ However, some scholars propose that even when the proportional-liability theory is used, there may be a threshold below which the damage would have to be ignored (as purely hypothetical damage) ${ }^{*} 83$ and another threshold above which full compensation could be awarded (where the probability reaches $90 \%$ or more). ${ }^{*} 84$

One possibility for resolution of uncertain causation cases is to use the "loss of chance"*85 test" ${ }^{* 86}$, in which the damage suffered is calculated in accordance with the percentage of the chance lost. ${ }^{*} 87$ The lossof-chance theory is suitable for victims who cannot, by using the balance of probabilities, prove that the defendant's behaviour caused the damage but who may be able to prove that they lost a chance to avoid the

76 CCSCd, 16.6.2010, 3-2-1-55-10, R.D. v. The Republic of Estonia, paragraph 30 (in Estonian); CCSCd, 21.5.2002, 3-2-1-56-02, OÜ Murbaran v. AS Remet and OÜ Stenhus, paragraph 24 (in Estonian).

77 CCSCd, 21.5.2002, 3-2-1-56-02, OÜ Murbaran v. AS Remet and Ö̈ Stenhus, paragraph 24 (in Estonian).

78 PETL (see Note 7), Article 3:102, Comment 8.

79 S. Deakin et al. (see Note 2), p. 326.

80 J. Stapleton (see Note 5) as cited in S. Deakin et al. (see Note 2), p. 1012.

81 S.M. Samii, A. Keirse (see Note 3).

$82 \quad$ F. Sobczak (see Note 51), p. 1165.

83 M.A. Jones. Textbook on Torts, 8th ed. Oxford: Oxford University Press 2002, pp. 231, 245.

84 T.K. Graziano (see Note 4), p. 1039.

85 To the best of my knowledge, Estonian courts have not discussed the loss-of-chance theory yet.

86 T. Tampuu (see Note 28), p. 174; S. Deakin et al. (see Note 2), pp. 325-327.

87 M.A. Jones (see Note 83), p. 243. 
damage. In my opinion, the plaintiff could say, for example, that if he had worked in conditions complying with the law there was a $75 \%$ chance of not falling ill with asbestosis or that he has lost a reasonable chance of employment. ${ }^{* 8}$ We should also ask what would have happened in the absence of negligence ${ }^{* 89}-$ e.g., if the failure to provide healthy work conditions caused the plaintiff's asbestosis. I argue that in the case of mesothelioma the theory of loss of a chance is not appropriate if the plaintiff had the mesothelioma before the defendant's breach of duty. But in the case wherein the plaintiff's health worsened after the defendant's infringement of regulations, it may be possible to apply the loss-of-chance theory. One example is the scenario in which the employer's breach of occupational safety regulations caused the deterioration in the plaintiff's health. Before the breach of duty, the probability of worsening of the victim's health was $50 \%$. The defendant may compensate the plaintiff for the $50 \%$ chance of maintaining the health condition he or she had before. In medical malpractice cases, ${ }^{*}{ }^{\circ 0}$ the object of protection is the victim's chance of recovery rather than the victim's health. ${ }^{*} 91$ The theory may be applicable also in toxic tort cases, ${ }^{*}{ }^{* 2}$ apart from those cases wherein the person's health was damaged before the defendant's breach of duty. ${ }^{*} 93$ Accordingly, the claim is likely to fail if a plaintiff demands application of the principle of loss of a chance when claiming that he would have been cured if it were not for the defendant's act.

I conclude, however, that the loss-of-chance theory may be applicable in cases involving unreasonable risky behaviour of the victim (e.g., not using proper protective equipment), noxious habits of the victim (ignoring risks and safety measures), and background risks (such as ambient air pollution). Even if possibly health-damaging circumstances are present, the plaintiff would have had a chance to avoid damage were if not for the defendant's harmful act. I conclude, however, that the loss-of-chance theory may be applicable in cases involving unreasonable risky behaviour of the victim (e.g., not using proper protective equipment), noxious habits of the victim (ignoring risks and safety measures), and background risks (such as ambient air pollution). Even if possibly health-damaging circumstances are present, the plaintiff would have had a chance to avoid damage were if not for the defendant's harmful act.Where there is a pre-existing health condition or a predisposition to the relevant illness, it should be assessed case-specifically whether there would have been any chance of avoiding the damage. For example, people who are more susceptible to cancer, such as those with weaker physiological protection mechanisms or a genetic predisposition to it, might get cancer while others do not. ${ }^{*} 94$

The English courts have applied the loss-of-chance test in the context of a 'more probable than not' test. ${ }^{*} 95$ Similarly to that with proportional liability, a threshold approach is proposed (when the probability reaches $90 \%$ or more, full compensation could be awarded). ${ }^{*}{ }^{6}$ In a contrast to the proportional-liability theory, in application of the loss-of-chance test, a threshold below which the damage would have to be ignored is not in use; in order to avoid paying, the defendant must show that the plaintiff had no chance to

88 Ibid., pp. 243-246.

89 Ibid., p. 245.

$90 \quad H a r d y$ v. Southwestern Bell Telephone Co., 910 P 2d 1024 (1996) as referred to in S. Deakin et al. (see Note 2), p. 327.

91 T.K. Graziano (see Note 4), p. 1022; S. Deakin et al. (see Note 2), p. 325.

92 One example of a medical malpractice case is the situation wherein a delay in diagnosis increases the likelihood of the disease leading to death, and an example of a toxic tort case is a situation in which a factory's polluting activity increases the risk of contracting of the disease suffered by the plaintiff. It may be very difficult or even impossible to establish whether the damage still would have occurred if the disease had been diagnosed sooner or if the employer had not acted negligently. Although we do not know whether the damage would have occurred without the defendant's behaviour as posited, in either case there is usually no doubt that the victim has lost the chance to avoid the disease. See T.K. Graziano (Note 4), pp. 1011-1012.

93 J. Stapleton (see Note 5), p. 1002. If the plaintiff had an incurable disease prior to the defendant's act, then the wrongdoer did not deprive the plaintiff of the possibility of maintaining his or her condition of health. For a valid claim to be submitted, actual damage to health must have occurred. If the possibility of preventing the health damage was reduced but no damage has been caused, it is not possible to claim damages. See K. Oliphant (Note 48), p. 1623.

94 B.T. Mossman et al. Particle and fibre toxicology (2007). Available at http://www.particleandfibretoxicology.com/content/4/1/4 (most recently accessed on 10.4.2014); See also M. Carbone, et al. A mesothelioma epidemic in Cappadocia: scientific developments and unexpected social outcomes. Nature Reviews Cancer (2007). Available at http://www.nature. $\mathrm{com} / \mathrm{nrc} /$ journal/v7/n2/full/nrc2068.html (most recently accessed on 2.4.2014) - DOI: http://dx.doi.org/10.1038/nrc2068.

95 Ibid., p. 1024.

96 L. Bieri, P. Marty (see Note 54), pp. 24-28. 
avoid the damage. ${ }^{*}{ }^{97}$ Hence, theoretically the loss-of-chance theory may be appropriate in cases wherein we cannot prove that a posited event happened or the probability of it having occurred is very low. ${ }^{*} 98$

I agree with T.K. Graziano, who finds that in cases of purely hypothetical damage, probabilities that remain below a certain borderline level would have to be ignored for practical reasons and for purposes of reduction of administrative costs. ${ }^{*} 99 \mathrm{~B}$. Markesinis has pointed out: 'The arguments against using loss of a chance theory are that this will lead to a multiplicity of new claims, giving rise to fresh evidential difficulties and complicating the relationship between different heads of damage. ${ }^{*} 100$

Scholars of common law have calculated the loss of a chance in several ways. One approach is very simple: if the probability of causation is, let us say, $40 \%$, the person has lost a $40 \%$ chance of survival in consequence of the defendant's behaviour, and loss of a chance for the victim to recover or to survive is in itself damage subject to compensation. ${ }^{*}{ }^{101}$

The second approach taken with the loss-of-chance theory is more complicated. For example, let us assume that the probability of causation is $92 \%$. Without polluting activity, there was a three per cent probability of the victim falling ill with cancer. On account of the defendant's breach of duty, there is a $39 \%$ probability of the plaintiff falling ill with cancer. The probability that the damage has arisen because of the defendant's breach of duty is $92 \%$, and the defendant has to pay the damages in full (100\%). If the probability that the victim is suffering from cancer because of the tortfeasor's breach of duty is instead $89 \%$ (if the probability of cancer without the defendant's behaviour is now four per cent ${ }^{* 102}$ ), then application of the loss-of-chance theory would mean that the defendant has to compensate for $50 \%$ (61\% less $11 \%$ ) of all the damages. At the same time, if proportional liability is applied, the defendant has to pay $89 \%$ of the total amount of damages. ${ }^{* 103}$ As can be seen from the above example, if the probability of damage is below $90 \%$, the amount of compensation may be smaller with the loss-of-chance theory than when proportional liability is applied. One can see that the outcomes differ between the loss-of-chance and proportional-liability theories. ${ }^{*} 104$ Because the loss-of-chance theory takes into account more risk factors, with their associated probabilities (the probability with and without the defendant's actions in question), the outcome may be more accurate than when the probability theory is used. Therefore, the loss-of-chance approach tends to be even more equitable for the two parties than the proportional-liability theory is, and Estonian courts may consider its application in cases involving uncertain causation within the victim's sphere.

\section{Conclusions}

Establishing causality is problematic when there are uncertain causes within the victim's sphere. Courts have to make decisions in situations wherein, on the one hand, a susceptible person has to bear the normal risk of living and, on the other hand, the plaintiff's state of health does not exclude the defendant's liability. For example, in the case of noxious habits of the plaintiff, the victim's opportunity to receive compensation may depend on the type of the disease-whether it is divisible or indivisible. In cases of divisible diseases, damages may be reduced if the plaintiff's contributory negligence or the victim's intent to cause damage can be shown. According to common law, however, if the plaintiff's fault was insubstantial, the reparation is

97 J. Tibballs. Loss of chance: A new development in medical negligence law. - The Medical Journal of Australia 187 (2007)/4, p. 235. Available at http://www.mja.com.au/public/issues/187_04_200807/tib10462_fm.html\#O_ pgfId-1091805 (most recently accessed on 10.4.2013).

98 M.A. Jones (see Note 83), p. 245.

99 T.K. Graziano (see Note 4), p. 1039.

100 S. Deakin et al. (see Note 2), p. 264.

101 T.K. Graziano (see Note 4), pp. 1022-1027.

102 The value is changed from three per cent because it is important for the outcome percentage to be below $90 \%$ in this example.

103 L. Bieri, P. Marty (see Note 54), pp. 24-28; D. Sõritsa. The health care provider's delictual liability. Master's thesis, 2012, p. 48 (in Estonian).

104 Ibid., p. 24. In the case of the loss-of-chance theory, the uncertainty is as to what would have happened in the absence of negligence (hypothetical fact). In the case of the probability theory, the uncertainty is as to a past fact-e.g., whether the defendant's negligence caused the plaintiff's loss of action. Regardless of this fact, it is said to be doubtful that the distinction between past and hypothetical facts constitutes an actual difference between those theories, because the past questions (e.g., whether the infringement of compulsory regulations caused the victim's health damage) depend on the answer to the hypothetical question (that of whether he or she would have abided by the rules). See also M.A. Jones (Note 83), p. 245. 
not to be reduced. Following the reasoning applied in this paper, I have come to the conclusion that in cases of indivisible diseases such as mesothelioma, it may not be possible to take into account such elements as the smoking history of the plaintiff and refuse to reduce damages accordingly. Therefore, the all-or-nothing approach is applicable in such a case. Furthermore, the plaintiff's weak health and predisposition to the illness do not automatically exclude the liability of the defendant. In cases of divisible diseases such as asbestosis, the loss-of-chance theory may be the most suitable. Therefore, it is my considered opinion that Estonian courts should apply liability theories based on probabilities in most cases of uncertain causation that involve divisible diseases.

Finally, in not all of the medical malpractice and toxic tort cases coming before it has the Supreme Court of Estonia taken into account the Fairchild exception, according to which the victim has to show that the defendant's behaviour 'materially increased the risk' of contracting the disease and need not prove a strict causal link between the defendant's unlawful act and the plaintiff's damage. The Supreme Court of Estonia has demanded that the plaintiff establish a strict causal link in one case of uncertain causation discussed in this paper. Since the Supreme Court of Estonia has said little about uncertain causation, especially with respect to decisions dealing with uncertain causes within the victim's sphere, it is important for the Estonian courts to take into account the principles provided for in the PETL, the DCFR, and decisions in common law. 